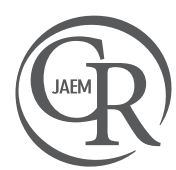

\section{Clinical Picture, Radiological Findings, and Physical Examination in Tracheobronchial Foreign Body Aspiration: Which One is More Important?}

\author{
Trakeobronşial Yabancı Cisim Aspirasyonunda Klinik, Radyoloji ve Fizik Muayene: \\ Hangisi Daha Önemli?
}

\author{
İsmail Ertuğrul Gedik', Timuçin Alar', Dilek Ömür2, Okhan Akdur³ \\ 'Department of Thoracic Surgery, Faculty of Medicine, Çanakkale Onsekiz Mart University, Çanakkale, Turkey \\ 2Department of Anesthesiology and Reanimation, Faculty of Medicine, Çanakkale Onsekiz Mart University, Çanakkale, Turkey \\ ${ }^{3}$ Department of Emergency Medicine, Faculty of Medicine, Çanakkale Onsekiz Mart University, Çanakkale, Turkey
}

\section{ABSTRACT}

Tracheobronchial foreign body aspiration is more frequent in children between 6 months-3 years of age, whereas it is seen less often in adults. The diagnosis of TBFB aspiration can be delayed in the adult population due to the lack of clinical suspicion. A case of a 56-year-old male patient admitted to the emergency department with a history of aspiration of a piece of carrot 4 hours previously, a cough and stridorous breathing is presented. His physical examination revealed reduced respiratory sounds in the lower zone of the left lung. There was no radiological clue of a tracheobronchial foreign body. Thus, we performed rigid bronchoscopy and found that the left lower lobe basal segment bronchus was almost totally obstructed by a foreign body (carrot) of $1.5 \times 1 \mathrm{~cm}$, which was removed. This was based on the clinical suspicion derived from the history and the physical examination alone. We emphasise that history and physical examination are more important in the diagnosis of organic or non-opaque tracheobronchial foreign body aspiration.

Keywords: Foreign body aspiration, tracheobronchial foreign body, rigid bronchoscopy

Received: 25.12.2012 Accepted: 26.01.2013

\section{ÖZET}

Trakeobronşial yabancı cisim aspirasyonu, 6 ay-3 yaş arasındaki çocuklarda daha sık görülen, buna karşılık erişkinlerde daha az izlenen bir durumdur. Genellikle erişkin yaştaki hastalarda trakeobronşial yabancı cisim aspirasyonundan şüphelenilmediği için tanıda gecikmeler yaşanmaktadır. Bu makalede 56 yaşında yaklaşık 4 saat önce havuç yerken bir parçasını aspire etme, öksürük ve hırıltılı solunum yakınmalarıyla acil servise başvuran bir erkek hasta sunuldu. Yapılan fizik muayenesinde sol alt sonda solunum seslerinde azalma mevcut olan hastada radyolojik olarak trakeobronşial yabancı cismi düşündürecek bir bulguya rastlanılmadı. Sadece öykü ve fizik muayene bulguları ışığında oluşan klinik şüphe ile hastaya bronkoskopi uygulandı ve sol alt lob bazal segment bronşunu tama yakın obstrükte eden yaklaşık 1,5x1 cm çapındaki yabancı cisim (havuç) tespit edilerek çıkartıldı. Biz de bu olgu sunumunda organik veya non-opak trakeobronşial yabancı cisim aspirasyonlarında öykü ve fizik muayene bulgularının önemini vurgulamayı amaçladık.

Anahtar Kelimeler: Yabancı cisim aspirasyonu, trakeobronşial yabanci cisim, rijid bronkoskopi

Geliş Tarihi: 25.12.2012 Kabul Tarihi: 26.01.2013

\section{Introduction}

Tracheobronchial foreign body (TBFB) aspiration is more frequent in children between 6 months-3 years of age, whereas it is seen less often in adults (1, 2). According to the United States National Safety Council's Injury Facts book of 2011, 4344 people died of TBFB aspiration in the USA in the year 2007 and that it has a mortality rate of 1.4/100000. In addition, TBFB aspiration is the fourth most common cause of unintentional deaths in the USA (3). The diagnosis of TBFB aspiration can be delayed in the adult population due to the lack of clinical suspicion. Cases of TBFB aspiration that remained undetected for a period up to 25 years have been reported (4). Patients who suffer from TBFB aspiration are usually admitted to the emergency depart- 


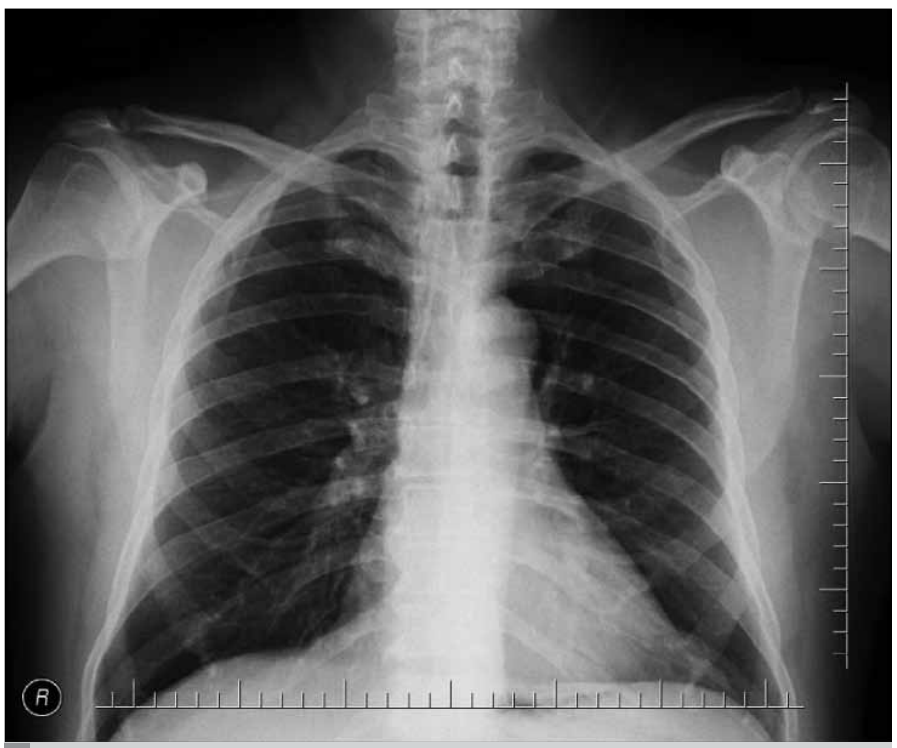

Figure 1. Chest X-ray taken immediately after the initial physical examination

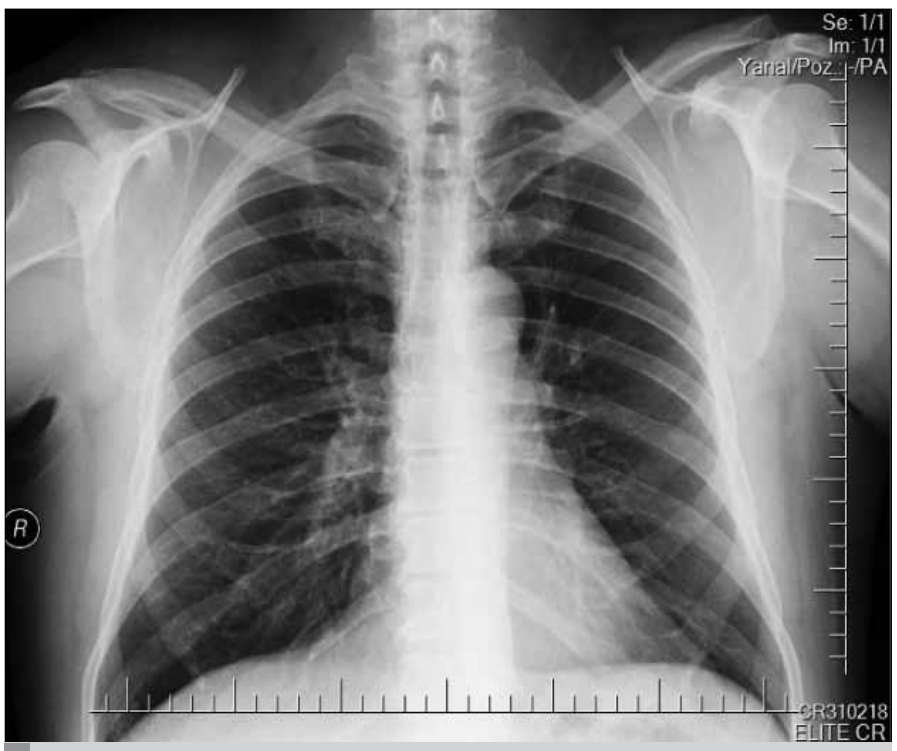

Figure 2. Chest X-ray taken after 8 hours of monitoring in the emergency department

ment in the acute setting, therefore emergency physicians are very important in the diagnosis and treatment of TBFB aspiration. In this report, we present a case of a 56-year-old male patient with a history of suspicious TBFB aspiration who presented to the emergency department, the diagnostic workup, and the treatment that was administered.

\section{Case Report}

A 56-year-old male patient was admitted to the emergency department with a history of aspiration of a piece of carrot during a meal 4 hours previously, a cough, and stridorous breathing. He had no prior history of such complaints and had a history of acetylsalicylate use of $150 \mathrm{mg} /$ day and a uvulopalatopharyngoplasty (UPPP) operation

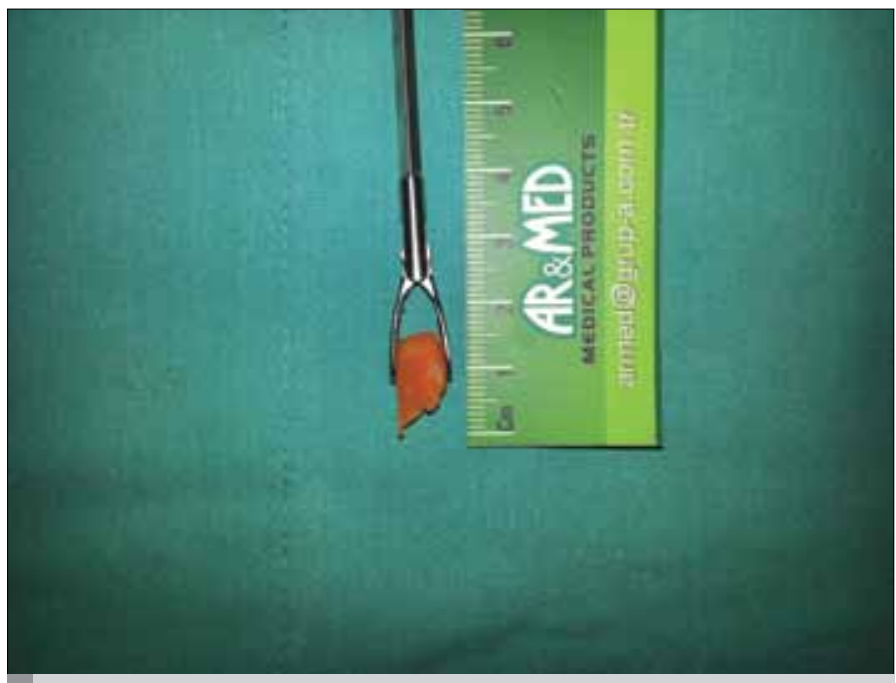

Figure 3. The orange-coloured foreign body with the dimensions of $1.5 \times 1 \mathrm{~cm}$ that was removed from the left lower lobe basal segment bronchus via rigid bronchoscopy

that was undertaken 9 years previously. No cyanosis or dyspnoea was detected in the patient. He was conscious and stable with the vital signs as folllows: blood pressure 158/78 $\mathrm{mmHg}$; heart rate 73 beats per minute; body temperature $36.5^{\circ} \mathrm{C}$; and respiration rate 21 breaths per minute. His $\mathrm{SatO}_{2}$ was $93 \%$ on room air. During auscultation, coarse respiratory sounds and wheezing were found in the left upper and middle zones and reduced respiratory sounds were found in the left lower zone. Examination of the remaining systems revealed no additional signs. The chest $\mathrm{X}$-ray taken after the physical examination showed no abnormality (Figure 1).

The patient was monitored with the following findings: there were no significant changes in the SatO, levels and his arterial blood gas evaluations were normal. The bronchospasm found in the examination was treated medically with salbutamol nebules ( $1 \mathrm{mg} / \mathrm{mL}$ ), O (2 L/min) was given via a nasal cannula, and respiratory physiotherapy was given. He was re-examined 8 hours after admission and the coarseness in the respiratory sounds in the left upper and middle zones were found to be alleviated but there was no significant change in the respiratory sounds of the left lower lobe. A new chest X-ray was performed immediately after the re-examination, which again did not reveal any abnormality (Figure 2).

The patient was taken into the operating room after we obtained his informed consent, because of the history and physical examination findings, despite no radiological proof of TBFB aspiration. An emergency rigid bronchoscopy was performed on the patient with an $8.5 \mathrm{~mm}$ rigid bronchoscope under oropharyngeal anaesthesia via lidocaine spray and sedoanalgesia via $2 \mathrm{mg}$ midazolam, 50 mg ketamine, 100 mg succinylcholine, and 200 mg total dose of propofol, which was administered intermittently. After passing through the left main bronchus and the upper lobe bronchial bifurcation, the left lower lobe basal segment bronchus was totally obstructed by a lesion that was covered with a white-coloured se- 
cretion. The lesion was found to be an orange-coloured foreign body after the aspiration of the secretion. The orange lesion with the dimensions of $1.5 \times 1 \mathrm{~cm}$ was removed with a clamp and found to be a piece of carrot (Figure 3). The operation ended after haemorrhage control and the patient was monitored in the recovery room with $\mathrm{O}_{2}(3 \mathrm{~L} / \mathrm{min})$ given via a nasal cannula until he recovered from sedation.

The patient was taken to the thoracic surgery ward 30 minutes later. His respiratory sounds were auscultated clearly and the postoperative physical examination was performed an hour later. He was monitored in the thoracic surgery ward for 24 hours and was discharged because of a normal physical examination, blood count and chest $X$-ray findings at the end of this period.

\section{Discussion}

Foreign body aspiration can be a life-threatening emergency, requiring prompt diagnosis and proper treatment. If left undiagnosed and untreated, TBFB aspiration may cause serious complications, such as atelectasis, bronchiectasis, obstructive pneumonia, pulmonary abscess, empyema, bronchial stricture, and haemoptysis. TBFB aspiration is uncommon in adults with a normal cough reflex, but in patients with neurological disorders, alcohol or intravenous drug abuse, sedative and hypnotic drugs, mental retardation, or psychotic disorders the incidence of TBFB aspiration increases (2). As described in another report, TBFB aspiration should be suspected in cases of stridorous breathing in adults who have undergone UPPP surgery (5). We could not detect any reason for the tendency to aspirate foreign bodies in our patient except for the UPPP operation he had had. He also had no prior history of admittance to a medical facility with the symptoms of a cough, stridorous breathing, and aspiration of a foreign body after the UPPP operation that he had 9 years previously.

The most important elements in the diagnosis of TBFB aspiration are the history and physical examination. A cough and shortness of breath are among the most common symptoms of TBFB aspiration (6). Our patient also had stridorous breathing besides a cough on admittance. Chest $X$-ray is the first modality of choice in the diagnosis of TBFB aspiration, despite the fact that it is not sometimes non-diagnostic $(7,8)$. Organic or non-opaque foreign bodies, especially, cannot be detected with radiological modalities. Our patient had stated that he had aspirated an organic foreign body and was admitted to the emergencey department with complaints including a cough and stridorous breating but his chest X-ray was nondiagnostic

The most successful modality in the diagnosis and treatment of TBFB aspiration is rigid bronchoscopy. Clinical suspicion of TBFB aspiration is the most important indication of bronchoscopy (6). Despite the fact that flexible bronchoscopy can also be used in the treatment of TBFB aspiration, its success rates are below that of rigid bronchoscopy (2). We decided to perform rigid bronchoscopy on our patient with the clinical suspicion of TBFB aspiration due to the history and the findings of physical examination, and managed to diagnose and treat him with rigid bronchoscopy.

\section{Conclusion}

We conclude that the presence of TBFB aspiration should be suspected in patients with acute onset of a cough and stridorous breathing even if there are no underlying predisposing factors. History and physical examination are more reliable than radiological modalities in the diagnosis of TBFB aspiration. Rigid bronchoscopy is the most reliable method when TBFB aspiration is suspected. Performing rigid bronchoscopy in the acute setting of TBFB aspiration prevents the serious complications that may occur in the future.

\section{Conflict of Interest}

No conflict of interest was declared by the authors.

Peer-review: Externally peer-reviewed.

\section{Author Contributions}

Concept - T.A., O.A.; Design - T.A., I.E.G.; Supervision - T.A., O.A.; Data Collection and/or Processing - I.E.G., D.Ö.; Analysis and/or Interpretation - T.A., D.Ö.; Literature Review - I.E.G.; Writer - I.E.G.; Critical Review - D.Ö., O.A.

\section{Çıkar Çatışması}

Yazarlar herhangi bir çıkar çatışması bildirmemişlerdir.

Hakem değerlendirmesi: Dış bağımsız.

\section{Yazar Katkıları}

Fikir-T.A., O.A.;Tasarım -T.A., I.E.G.; Denetleme-T.A., O.A.;VeriToplanmas ve/veya Işlemesi - I.E.G., D.Ö.; Analiz ve/veya Yorum - T.A., D.Ö.; Literatür Taraması - I.E.G.; Yazıyı Yazan - I.E.G.; Eleştirel İnceleme - D.Ö., O.A.

\section{References}

1. Güzel A, Güzel A, Tekin M, Ayvaz S, Aksu B. Trakeobronchial toy bow in a seven years old child: Case report. JAEMCR 2011; 2: 42-4. [CrossRef]

2. Limper AH, Prakash UB. Tracheobronchial foreign bodies in adults. Ann Intern Med 1990; 112: 604-9. [CrossRef]

3. National Safety Council. Injury Facts, 2011 Edition. Itasca, IL: Author. 2011.p.10-5

4. Al-Majed, Ashour M, Al-Mobeireek, Al-Hajjaj MS, Alzeer AH, Al-Kattan K. Overlooked inhaled foreign bodies: late sequelae and the likelihood of recovery. Respir Med 1997; 91: 293-6. [CrossRef]

5. Çelebioğlu B, Özer E, Çeliker V. Unsuspected Mechanical Airway Obstruction in Obstructive Sleep Apnea Syndrome. A \& A 2004; 98: 1813-4.

6. Gürsu S, Sırmalı M, Gezer S, Fındık G, Türüt H, Aydın E, ve ark. Yetişkinlerde trakeobronşiyal yabancı cisim aspirasyonları Turkish J Thorac Cardiovasc Surg 2006; 14: 38-41.

7. Zissin R, Sharpio-Feinberg M, Rozenman J, Apter S, Smorjik J, Hertz M. $\mathrm{CT}$ findings of the chest in adults with aspirated foreign bodies. Eur Radiol 2001; 11:606-11. [CrossRef]

8. Gang W, Zhengxia P, Hongbo L, Yonggang L, Jiangtao D, Shengde W, et al. Diagnosis and treatment of tracheobronchial foreign bodies in 1024 children. J Pediatric Surg 2012; 47: 2004-10. [CrossRef] 